\title{
Dynamics of bacteria and mixotrophic flagellates in an Alpine lake in relation to Daphnia population development
}

\author{
Cristiana CALLIERI*, Roberto BERTONI and Gianluca CORNO ${ }^{1)}$ \\ CNR Istituto per lo Studio degli Ecosistemi, L.go V. Tonolli 50, 28922 Verbania Pallanza, Italy \\ ${ }^{1)}$ Max-Planck-Institut für Limnologie, August Thienemann Straße 2, 24306 Plön, Germany \\ *e-mail corresponding author: c.callieri@iii.to.cnr.it
}

\begin{abstract}
In a fishless oligotrophic Alpine lake (Lago Paione Superiore: LPS), with a simple trophic food web, the relationships between microorganisms and zooplankton have been studied. During the ice-free period 1999, bacterial grazing by mixotrophic flagellates $(M x F l)$, autotrophic carbon fixation and excretion (EOC), bacterial production, and zooplankton abundance and biomass were measured weekly. After ice-melt, MxFl, which constituted $94 \%$ of total phytoplankton, increased in number until the appearance of Daphnia longispina, the dominant crustacean zooplankton species in LPS. Gross primary production and EOC ranged from 0.2 to 2.5 and from 0.1 to $1.8 \mu \mathrm{g} \mathrm{Cl} \mathrm{r}^{-1} \mathrm{~h}^{-1}$, respectively. EOC accounted for 45 to $90 \%$ of total autotrophic production. Community grazing

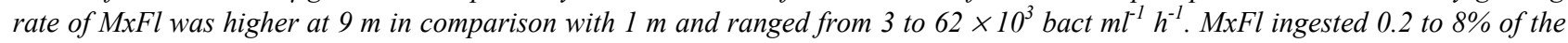
natural bacterioplankton per hour, in summer. The community grazing rate of mixotrophic flagellates was significantly correlated with the phytoplanktonic photosynthetic activity $(P=0.006)$ and with the bacterial production $(P=0.037)$. In August, Daphnia grazing caused a rapid decrease of both bacteria and $M x F l$ and of their activities. Phytoplankton photosynthetic efficiency increased in late summer after a phosphorus pulse. Although P excretion by zooplankton was not measured, it is speculated that Daphnia play an important role in the availability of this element firstly by grazing bacteria and MxFl in the water column and, after the exhaustion of such food, by browsing algae at the water-sediment interface.
\end{abstract}

Key words: Alpine lakes, microbial food web, mixotrophic flagellate grazing, Daphnia longispina

\section{INTRODUCTION}

High mountain lakes, situated above the timberline, are generally oligotrophic, due to the small catchment area with poor vegetation, and have a rather simple pelagic food web (Straškrabová et al. 1999). This is the case of Lago Paione Superiore (LPS), a small (0.014 $\mathrm{km}^{2}$, max depth: $11.7 \mathrm{~m}$ ), glacial lake in the Central Italian Alps (Val Bognanco, Pennine Alps, 2269 m a.s.l.). It is a fishless oligotrophic lake, acidic due to low alkalinity and the acidification processes common to many European lakes (The MOLAR Water Chemistry Group 1999). LPS has been intensively studied in recent years and is the site selected within the Italian Alps by different groups of the European Community upon which to evaluate effects of acid rain on lakes (AL:PE and MOLAR Project). Previous studies (Callieri \& Bertoni 1999) showed that in LPS approximately $75 \%$ of the total organic carbon is in the dissolved form (DOC) and fluctuates greatly during the season. The microbial food web is composed mainly of bacteria and mixotrophic flagellates $(\mathrm{MxFl})$, while ciliates, heterotrophic flagellates and strictly autotrophic phytoplankton are lower in both number and biomass (Callieri \& Bertoni 1999; Pugnetti \& Bettinetti 1999). Immediately after thaw, bacteria and mixotrophic flagellates prevail; then follows a development of considerable zooplankton biomass comprising mainly Daphnia longispina (Manca
\& Comoli 1999). We chose this small Alpine lake to study $\mathrm{MxFl}$ and their relationships with bacteria and zooplankton. Studies on mixotrophic phytoplankton based on laboratory experiments have clarified functional aspects of Chrysophytes (e.g. Ochromonas: Andersson et al. 1989; Rothhaupt 1996, 1997; Dinobryon: Jones \& Rees 1994) and of Cryptophytes (Gervais 1997; Tranvik et al. 1989) and a classification of MxFl based on their behaviour has been proposed (Jones 1997; Jones 2000), which integrated also results from the field. MxFl have been studied in different freshwater environments: from humic lakes of northern Europe (Jansson et al. 1999; Jansson et al. 1996; Salonen \& Jokinen 1988) to Antarctic lakes (Roberts \& LaybournParry 1999) or eutrophic lakes and ponds (Urabe et al. 2000; Hitchman \& Jones 2000). So far no study has been performed on the functional ecology of $\mathrm{MxFl}$ in high mountain lakes although the presence and importance of $\mathrm{MxFl}$ in the phytoplankton of such lakes has been widely recorded (Simona et al. 1999; MedinaSánchez et al. 1999; Pugnetti \& Bettinetti 1999). In this paper we discuss the role of phagotrophic activity of $\mathrm{MxFl}$ on bacteria and of Daphnia longispina on microbial communities.

\section{MATERIAL AND METHODS}

Samples were taken during the ice-free period of 1999 from a station above the point of maximum depth. 
Chrom. \& Phyto tot. (ind $\mathrm{ml}^{-1}$ )

others (ind $\mathrm{ml}^{-1}$ )
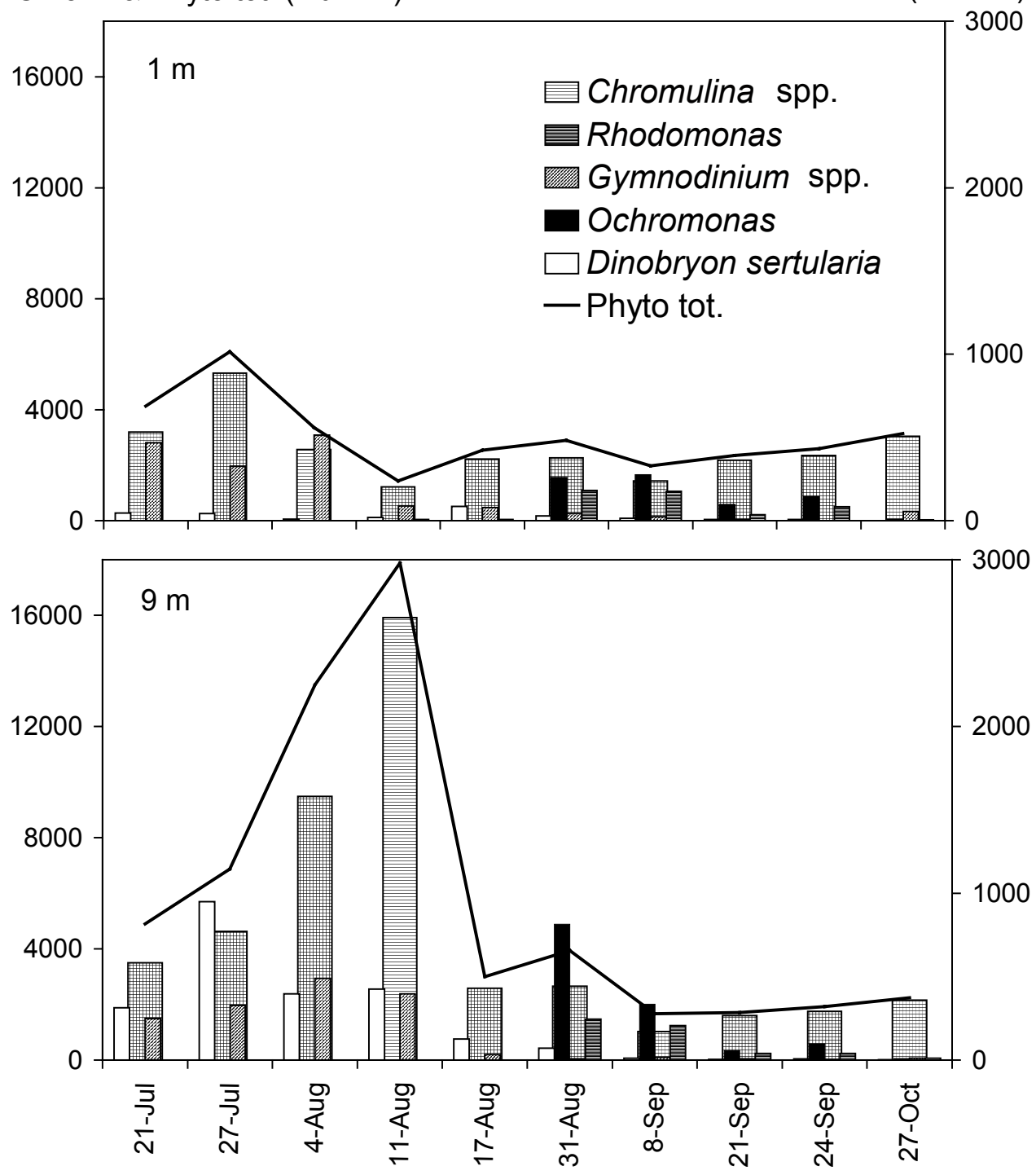

Fig. 1. Dynamics of mixotrophic flagellates in LPS during summer 1999. The histograms are the number of organisms for the more representative species and the line is the total phytoplankton abundance.

A total of 10 sampling occasions were performed from July to October (see figure 1 for the sampling dates). Activities were not measured on the first and the last sampling dates. Two sampling depths were chosen: $1 \mathrm{~m}$ below the surface and $1 \mathrm{~m}$ above the bottom (which often corresponded to $9 \mathrm{~m}$ ). Underwater radiation and temperature were measured at each sampling date. Reactive phosphorus was determined (molybden blu, Mosello R. and Tartari G., personal communication).

Samples for abundance counts were fixed following the protocols presented in Straškrabová et al. (1999). The dry weight of zooplankton, collected by vertical net hauls (126 $\mu \mathrm{m}$ mesh), was measured and the carbon content determined with CHN analyser (ANA 1500, C. Erba). The photosynthetic activity was determined from ${ }^{14} \mathrm{C}$ uptake in light and dark bottles, after four hour in situ incubation of replicate samples pre-filtered through a $126 \mu \mathrm{m}$ net (Steeman Nielsen 1951). Net primary production was measured on $2 \mu \mathrm{m}$ Nuclepore filters. Since autotrophic picoplankton are negligible in LPS (Callieri $\&$ Bertoni 1999) we used a filter of $2 \mu \mathrm{m}$ to concentrate phytoplankton and measured the extracellular production (EOC) in the filtrate. The heterotrophic bacterial activity was determined from ${ }^{3} \mathrm{H}$-Thymidine uptake after one hour in situ incubation of triplicate samples prefiltered through a $126 \mu \mathrm{m}$ net. The mixotrophic grazing of bacteria was estimated from direct-uptake experiments, counting the fluorescently labeled bacteria (FLB) inside the vacuoles of the MxFl over time $(0,6,10,20$, $30 \mathrm{~min}$ ) (Sherr \& Sherr 1993). Bacteria were labeled with DTAF [5-(4,6-diclorotriazin-2-yl) aminofluorescein]. The FLB were added (up to $10-25 \%$ of lake-bac- 
teria abundance) to 1.51 replicate samples, and incubated in situ under low light immediately after sampling. After DAPI staining, 200-300 MxFl were inspected under epifluorescence microscopy. Total phytoplankton was counted by inverted microscope in a sedimentation chamber and distinction made between mixotrophic and strictly autotrophic species. Bacteria were enumerated under epifluorescence microscopy (DAPI stained) and measured with image analysis (Optimas, Bioscan). Conversion factors and other methodological specifications are summarized in Straškrabová et al. (1999).

\section{RESULTS}

From June to September 1999 phytoplankton was mainly composed of potentially mixotrophic species (MxFl) with dominance of Chrysophyceae (Chromulina spp., Dinobryon sertularia and Ochromonas sp.) both at 1 and 9 m (Fig. 1). Dinophyceae (Gymnodinium ordinatum, Peridinium sp.) appeared in June/July as well as Chlorophyceae (Chlamydomonas sp.) whereas Cryptophyceae (Rhodomonas sp. and Cryptomonas sp.) peaked in August. During the ice-free period the MxFl constituted on average $94 \%$ and $79 \%$ of the total phytoplankton number and biomass respectively. Only one strictly autotrophic species, Mallomonas alveolata, was abundant in August $\left(2.7 \times 10^{3}\right.$ cells $\left.\mathrm{ml}^{-1}\right)$. The highest phytoplankton abundance $\left(18 \times 10^{3}\right.$ cells $\left.\mathrm{ml}^{-1}\right)$ as well as biomass $\left(1.1 \times 10^{3} \mathrm{~mm}^{3} \mathrm{~m}^{-3}\right.$, data not shown) were found at $9 \mathrm{~m}$ in August.

Bacteria, both cocci and rods, were quite constant in size (range: $0.33-0.75 \mu \mathrm{m}^{3}$ ). Occasionally filamentous forms appeared, in coincidence with heavy rain. These never exceeded $5 \%$ of total bacterial number and their biomass was not measured separately. The mean total bacteria abundance was $650 \times 10^{3}$ cells $\mathrm{ml}^{-1}$ (range: $450-820 \times 10^{3}$ cells $\left.\mathrm{ml}^{-1}\right)$. Bacterial and $\mathrm{MxFl}$ biomass (1-9 $\mathrm{m}$ average) decreased from July to September and the cell specific photosynthesis increased in late August /September (Fig. 2).

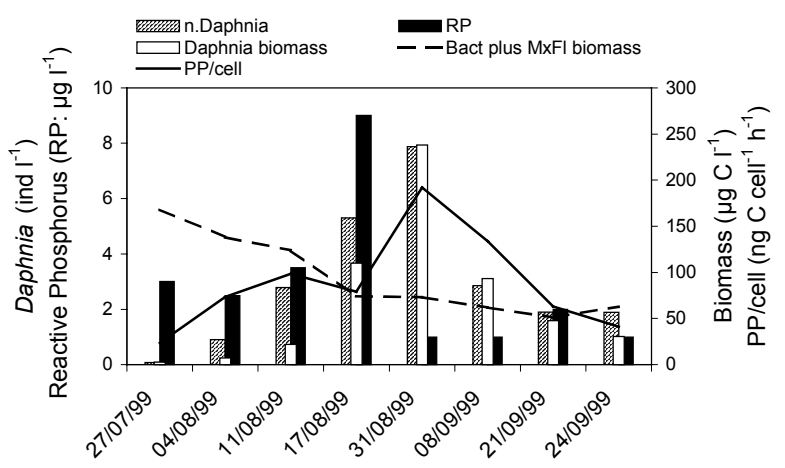

Fig. 2. Daphnia longispina population density, zooplankton biomass, reactive phosphorus, bacterial plus MxFl biomass, cell specific photosynthetic activity, calculated as a mean of the two depths, in LPS during summer 1999.
Zooplankton were composed of rotifers (Keratella quadrata), copepods (Cyclops abyssorum tatricus), and the cladoceran Daphnia longispina which was the dominant species. Daphnia abundance increased from 1 ind $1^{-1}$ (August $4^{\text {th }}$ ) to 8 ind $1^{-1}$ (August $30^{\text {th }}$ ) with a corresponding increase in biomass (238 $\mu \mathrm{g} \mathrm{C}^{-1}$, Fig. 2). This situation was similar to that reported by Manca $\&$ Comoli (1999). Reactive Phosphorus (RP) (1-9 m average) showed low values, around 1-3 $\mu \mathrm{g} \mathrm{l}^{-1}$, from July to September and an unexpected peak on $17^{\text {th }}$ August (Fig. 2).

Community grazing rate of $\mathrm{MxFl}$ was higher at $9 \mathrm{~m}$ relative to $1 \mathrm{~m}$ and ranged from 0.2 to $3.96 \mu \mathrm{g} \mathrm{C}^{-1} \mathrm{~h}^{-1}$. In summer $\mathrm{MxFl}$ ingested from 0.2 to $8 \%$ of the total bacterial population per hour. Net primary production ranged from 0.03 to $0.94 \mu \mathrm{g} \mathrm{C}^{-1} \mathrm{~h}^{-1}$, EOC from 0.12 to $1.79 \mu \mathrm{g} \mathrm{C} \mathrm{l}^{-1} \mathrm{~h}^{-1}$ and gross primary production from 0.2 to $2.5 \mu \mathrm{g} \mathrm{C}^{-1} \mathrm{~h}^{-1}$. On average the photosynthetic rates measured at $9 \mathrm{~m}$ were higher than those at $1 \mathrm{~m}$ and the EOC production accounted for 46 to $91 \%$ of the total production. Photosynthetic activity of total phytoplankton (net production $>2 \mu \mathrm{m}$ ) and MxFl community grazing rate fluctuated simultaneously, with higher $\mathrm{MxFl}$ grazing rate measured during peaks of production (Fig. 3 ). Production ( $\mathrm{PP}>2 \mu \mathrm{m}$ plus EOC): grazing ratio was always higher than 1.0 at $1 \mathrm{~m}$, while at $9 \mathrm{~m}$ ranged from 0.5 to 7.6 .
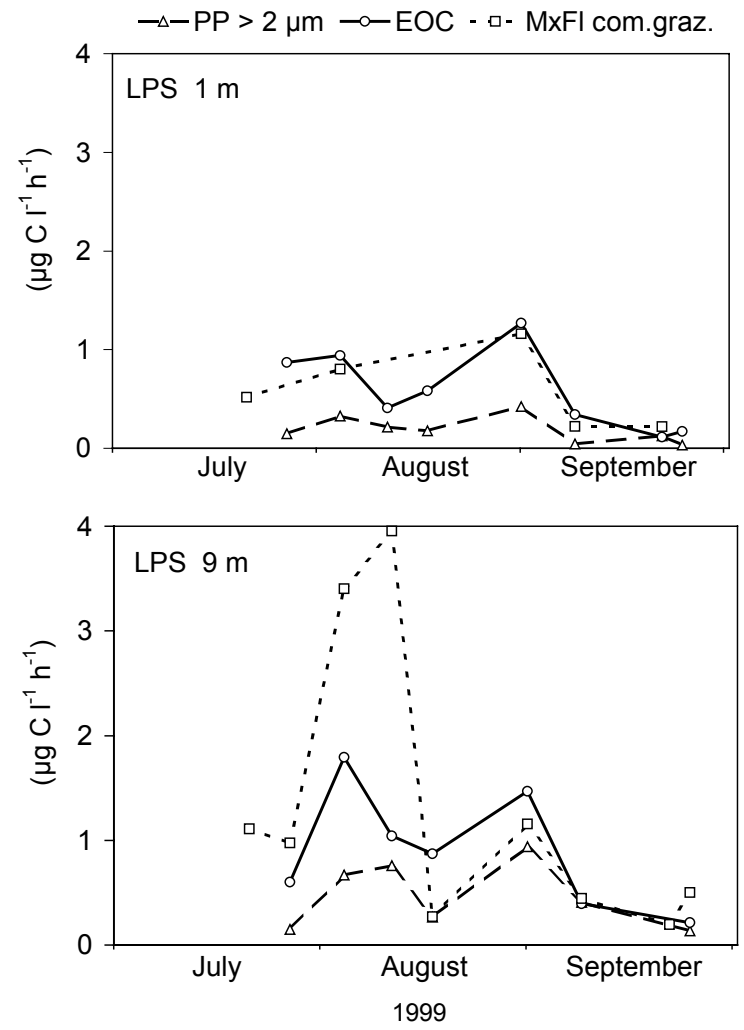

Fig. 3. Activities of mixotrophic flagellates: carbon production of $>2 \mu \mathrm{m}$ fraction, excreted carbon (EOC) and $\mathrm{MxFl}$ community grazing rate at 1 and $9 \mathrm{~m}$ in LPS, during summer 1999. 
Pooling all data together (1-9 m), a significant correlation between photosynthetic activity of total phytoplankton and the phagotrophic activity of $\mathrm{MxFl}$ was found (individual grazing, bact ind ${ }^{-1} \mathrm{~h}^{-1}: \rho$ Spearman $=$ 0.755 , d.f. $=10, \mathrm{P}=0.006$; community grazing, bact $\mathrm{ml}^{-1}$ $\mathrm{h}^{-1}: \rho$ Spearman $=0.800$, d.f. $=10, \mathrm{P}=0.002$ ). No significant correlation was found between grazing activity and EOC production. Furthermore the community grazing rate of $\mathrm{MxFl}\left(\mu \mathrm{g} \mathrm{C}^{-1} \mathrm{~h}^{-1}\right)$ and the bacterial production (BP Thymidine) were significantly correlated ( $\rho$ Spearman $=0.610$, d.f. $=10, P=0.037$ ). Maximum bacterial production $\left(5.1 \mathrm{pmol}^{-1} \mathrm{~h}^{-1}\right)$ and community grazing rate (range: $3-62 \times 10^{3}$ bact $\mathrm{ml}^{-1} \mathrm{~h}^{-1}$ ) were found in August, and afterwards there was a gradual decrease until September (Fig. 4).

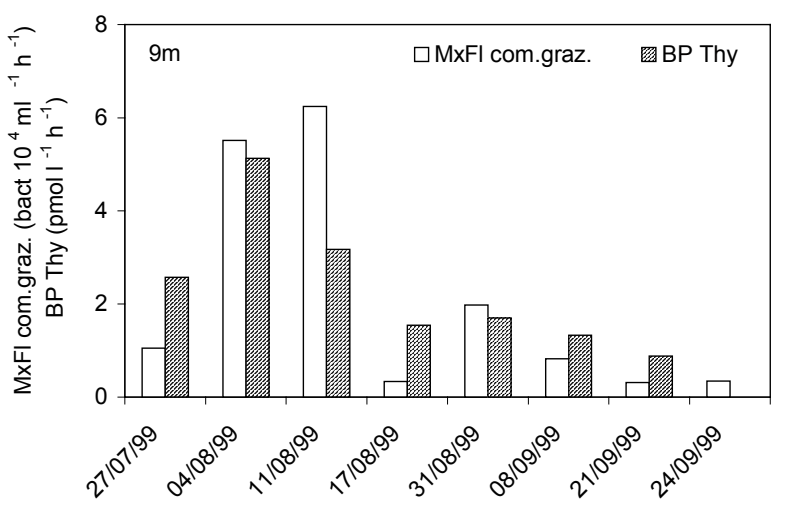

Fig. 4. Total bacterial activity measured with ${ }^{3} \mathrm{H}$-Thymidine incorporation (BP Thy) and MxFl community grazing rate at 9 $\mathrm{m}$, in LPS during summer 1999.

\section{DISCUSSION}

\subsection{Mixotrophic flagellates and bacteria}

Immediately after ice-melt, bacteria were the only organisms able to exploit the large amount of DOC present in the lake. At that time the high $\mathrm{C}: \mathrm{P}$ values (around 350:1) indicated a P limitation (Bertoni et al. in press), similarly observed in other lakes (Hochstädter 2000). At low P concentrations bacteria out-compete phytoplankton, owing to their higher affinity for phosphate (Currie \& Kalff 1984; Jansson 1993). During this period bacterial production reached maximum values (5.1 pmol $\left.\mathrm{l}^{-1} \mathrm{~h}^{-1}\right)$. To overcome nutrient limitations, phytoplankton (mainly composed of mixotrophs), had to supplement photosynthetic activity with phagotrophy. The significant correlation between $\mathrm{MxFl}$ grazing and bacterial activity corroborates this supposition. Mixotrophic species were favoured under conditions of nutrient depletion as they were able to obtain $\mathrm{P}$ and $\mathrm{N}$ from bacteria as substitutable nutrients (Nygaard \& Tobiesen 1993; Urabe et al. 2000). A similar situation has been described for a humic lake in Sweden (Jansson et al. 1999), where MxFl assume dominance via bacterivory. Our new data on mixotrophic flagellate activity demon- strate the significant role they have in the microbial food web of a clear Alpine lake.

In September C:P ratio of seston was low, $\mathrm{P}$ was therefore less limiting, bacteria less competitive with phytoplankton and the result was an increase of photosynthetic activity. The bimodal pattern of MxFl activity, with a prevalence of phagotrophy in July/August and of photosynthetic activity in September corresponded to a succession of different phytoplankton species. Dinobryon sertularia and Gymnodinium ordinatum prevailed in early summer followed by Ochromonas sp. and Rhodomonas sp. Two species of Chromulina were continually present reaching a maximum ingestion rate on July $21^{\text {st }}$ ( 7 bact ind $^{-1} \mathrm{~h}^{-1} ; \mathrm{C}$. Callieri, unpublished data).

Whilst the Chrysophycean Ochromonas sp. is considered a mixotrophic species with heterotrophy as the primary mode of nutrition (Pringsheim 1952; Anderson et al. 1989; Jones 2000), Rhodomonas lacustris (Cryptophyceae) has been classified as potentially mixotrophic (Jansson et al. 1996), that is to say primarily phototrophic but with some degree of bacterivory. Working with natural assemblages under epifluorescence microscopy, it was not possible to distinguish absolutely between the two genera but a general increase in the individual grazing rate with the appearance of Ochromonas was observed. The rise of photosynthetic efficiency after $17^{\text {th }}$ August can be attributed to the effect of a $\mathrm{P}$ pulse on mixotrophic species more phototrophically oriented, such as Rhodomonas sp.

It was assumed that in LPS, phytoplankton photosynthesis was due mainly to $\mathrm{MxFl}$ as they represented $94 \%$ of total algal abundance during summer 1999 . The direct correlation between photosynthetic and phagotrophic activity of $\mathrm{MxFl}$ therefore indicates 1) a balance in the species composition of $\mathrm{MxFl}$ with regard to their primary mode of nutrition; 2) simultaneity of photosynthesis and grazing, not mutually exclusive in mixotrophic species. From the study of species succession we noticed both in July/August and in September the presence of primarily phototrophic (Dinobryon sertularia or Rhodomonas sp.) and primarily heterotrophic species (Chromulina spp. or Ochromonas sp.). Dinobryon sertularia has been included in group C (Jones 1997; Jones \& Rees 1994) as an obligate phototroph with bacterial ingestion proportional to light intensity. Rhodomonas has been classified as mostly autotrophic, but potentially mixotrophic. Chromulina and Ochromonas (group A) have been described as efficient phagotrophic species in a highly humic lake (Salonen \& Jokinen 1988).

Extracellular primary production (EOC) was high in LPS and exceeded the net primary production (fraction $>2 \mu \mathrm{m}$ ). This situation is typical for oligotrophic high mountain lakes: in a study on nine mountain lakes the gross primary production ranged between 0.7 and 2.7 $\mu \mathrm{g} \mathrm{Cl}^{-1} \mathrm{~h}^{-1}$ and EOC accounted for between 5 and $75 \%$ of the total gross production (Straškrabová et al. 1999) 
and the values obtained fell within the range reported in other studies (e.g. La Caldera, Reche et al. 1996). Yet the amount of excreted carbon released can be highly variable if the winter time is also considered, as reported in Lake Redó (EOC: $5-80 \%$ of total production, Camarero et al. 1999).

\subsection{Microorganisms-Daphnia interactions}

The majority of non-detritic organic carbon of LPS trophic chain originates from bacteria, mixotrophic flagellates and zooplankton, in the water free period (Bertoni et al. in press). The carbon allocation between the dominant microorganisms of the microbial food web and the zooplankton showed that bacteria constitute a fairly constant carbon reserve, whereas MxFl are a consistent carbon reserve in July, replaced by Daphnia in late August. Before August $17^{\text {th }}$, much of the biomass was confined at $9 \mathrm{~m}$ with $8-18 \%$ of surface PAR (C. Callieri, unpublished data), protected from the harmful UV radiation and high PAR intensities. On August $17^{\text {th }}$, throughout the water column, there was a decrease of phytoplankton and bacteria with a minimum of autotrophic and heterotrophic activity, suggestive of a clearwater phase. Daphnia grazing (measured in concurrent experiments; Riccardi, in press) ranged from 19 to 192 $\times 10^{3}$ cell ind $^{-1} \mathrm{~h}^{-1}$ (for algae) and from 700 to $3300 \times$ $10^{3}$ cell ind $^{-1} \mathrm{~h}^{-1}$ (for bacteria). Previous studies performed during 1996-97-98 (Callieri et al. 1999) showed that the diet of Daphnia in LPS can extend to protozoa and bacteria. In other lakes it has been shown that Cladocerans consume bacterial production during population peaks (Vaquè \& Pace 1992; Jürgens 1994) like in LPS, where the maximum Daphnia grazing on bacteria was just in early August (data not shown), when bacterial production was high.

The increase of reactive phosphorus (RP) at 1 and 9 $\mathrm{m}$ on August $17^{\text {th }}$ cannot be explained by allochthonous inputs nor by resuspension from the sediments, because of the absence of heavy rain and the presence of thermal stratification (Bertoni et al. in press). Zooplankton excretion could have caused $\mathrm{P}$ increase in the lake. It is known from literature the role of zooplankton in increasing the availability of inorganic and organic nutrients via excretion or sloppy feeding (Sterner et al. 1995; Reche et al. 1997). Carrillo et al. (1996) measured the rate of $\mathrm{P}$ recycling in a high-mountain oligotrophic lake. They assessed an high rate which reached $1.6 \mu \mathrm{g} \mathrm{P}^{-1}$ $\mathrm{d}^{-1}$, with maxima in midsummer. Although $\mathrm{P}$ excretion by zooplankton was not measured, it is speculated that Daphnia plays an important role in the availability of this element firstly by grazing bacteria and $\mathrm{MxFl}$ in the water column and, after the exhaustion of such food, by browsing algae at the water-sediment interface. The subsequent phosphorus excretion by Daphnia during the diel vertical migration could explain the increase of this element throughout the water column. P mobilization by microzooplankton was deemed negligible since neither ciliates (G. Corno, unpublished data) nor the main rotifer species, Keratella quadrata, reached significant biomass.

In conclusion the small oligotrophic Lago Paione Superiore proved ideal for studying microbial loop relationship with Daphnia due to the absence of fish, the simplified food web and the almost exclusive presence of Daphnia longispina as the dominant zooplankter. The research performed during summer 1999 clarified various aspects of the role of bacteria, mixotrophic flagellates and zooplankton:

- Immediately after ice melt, bacteria were the most active organisms and out-competed phytoplankton in an environment poor in $\mathrm{P}$ and rich in dissolved organic carbon.

- Phytoplankton developed due to predominantly mixotrophic species which were able to ingest bacteria to obtain the necessary nutrients.

- MxFl grazing was positively correlated to bacterial activity and to phytoplankton photosynthesis.

- The increase of mixotrophs supported the development of zooplankton and in particular of Daphnia longispina, leading to a clear-water phase in mid August.

- The shallow depth of LPS and the transparency of water column allows photosynthetic organisms to thrive near the bottom of the lake. By vertical migration through water column, Daphnia can graze when food is scarce in the uppermost layer.

- Phosphorus mobilization from the water-sediment interface resulted in a pulse of $\mathrm{P}$ in the whole water column favouring photosynthetic activity of mixotrophs.

\section{ACKNOWLEDGMENTS}

We wish to thank Dr. R. Mosello and his staff for providing phosphorus data and Dr. Jon Grey for correcting English on a first draft of the manuscript.

\section{REFERENCES}

Andersson, A., S. Falk, G. Samuelsson \& A. Hagström. 1989. Nutritional characteristics of a mixotrophic nanoflagellates, Ochromonas sp. Microb. Ecol., 17: 251-262.

Bertoni, R., C. Callieri \& G. Corno. 2002. The mixotrophic flagellates as key organisms from DOC to Daphnia in a oligotrophic Alpine lake. Verh. int. Ver. Limnol., 28: (in press).

Callieri, C. \& R. Bertoni. 1999. Organic carbon and microbial loop assemblages in a oligotrophic high mountain lake. $J$. Limnol., 58(2): 136-143.

Callieri, C., A. Pugnetti \& M. Manca. 1999. Carbon partitioning in the food web of a high mountain lake: from bacteria to zooplankton. J. Limnol., 58(2): 144-151.

Camarero, L., M. Felip, M. Ventura, F. Bartumeus \& J. Catalan. 1999. The relative importance of the planktonic food web in the carbon cycle of an oligotrophic mountain lake in a poorly vegetated catchment (Redó, Pyrenees). J. Limnol., 58(2): 203-212.

Carrillo, P., I. Reche \& L. Cruz-Pizarro. 1996. Quantification of the phosphorus released by zooplankton in an oligo- 
trophic lake (La Caldera, Spain): regulating factors and adjustment to theoretical-models. J. Plankton Res., 18: $1567-1586$.

Currie, D.J. \& J. Kalff. 1984. A comparison of the abilities of freshwater algae and bacteria to acquire and retain phosphorus. Limnol. Oceanogr., 29: 298-310.

Gervais, F. 1997. Light-dependent growth, dark survival, and glucose uptake by Cryptophytes isolated from a freshwater chemocline. J. Phycol., 33: 18-25.

Hichman, R.B. \& H.L.J. Jones. 2000. The role of mixotrophic protists in the population dynamics of the microbial food web in a small artificial pond. Freshwat. Biol., 43: 231241.

Hochstädter, S. 2000. Seasonal changes of C:P ratios of seston, bacteria, phytoplankton and zooplankton in a deep, mesotrophic lake. Freshwat. Biol., 44: 453-462.

Jansson, M. 1993. Uptake, exchange and excretion of orthophosphate starved Scenedesmus quadricauda and Pseudomonas K7. Limnol. Oceanogr., 38: 1162-1178.

Jansson, M., A.K. Bergström, P. Blomqvist, A. Isaksson \& A. Jonsson. 1999. Impact of allochthonous organic carbon on microbial food web carbon dynamics and structure in Lake Örträsket. Arch. Hydrobiol., 144: 409-428.

Jansson, M., P. Blomqvist, A. Jonsson \& A.K. Bergström. 1996. Nutrient limitation of bacterioplankton, autotrophic and mixotrophic phytoplankton, and heterotrophic nanoflagellates in Lake Örträsket. Limnol. Oceanogr., 41: 1552-1559.

Jones R.I. 2000. Mixotrophy in planktonic protists: an overview. Freshwat. Biol., 45: 219-226.

Jones, H.L.J. 1997. A classification of mixotrophic protists based on their behaviour. Freshwat. Biol., 37: 35-43.

Jones, R.I. \& S. Rees. 1994. Influence of temperature and light on particle ingestion by freshwater phytoflagellate Dinobryon. Arch. Hydrobiol., 132: 203-211.

Jürgens, K. 1994. Impact of Daphnia on planktonic microbial food web. A review. Mar. Microb. Food Webs, 8: 295 324.

Manca, M. \& P. Comoli. 1999. Studies on the zooplankton of Lago Paione Superiore. J. Limnol., 58(2): 131-135.

Medina-Sánchez, J.M., M. Villar-Argaiz, P. Sánchez-Castillo, L. Cruz-Pizarro \& P.Carrillo. 1999. Structure changes in a planktonic food web: biotic and abiotic controls. $J$. Limnol., 58(2): 213-222.

Nygaard K. \& A. Tobiesen. 1993. Bacterivory in algae: a survival strategy during nutrient limitation. Limnol. Oceanogr., 38: 273-279.

Pringsheim, E.G. 1952. On the nutrition of Ochromonas. Quart. J. Microsc. Sci., 93: 71-96.

Pugnetti, A. \& R. Bettinetti. 1999. Biomass and species structure of the phytoplankton of an high mountain lake (Lake Paione Superiore, Central Alps, Italy). J. Limnol., 58(2): 127-130.

Reche, I., A. Pugnetti, L. Cruz-Pizarro \& P. Carrillo. 1996. Relationship between bacteria and phytoplankton in a high-mountain lake: importance of the organic carbon released by pelagic algae for bacterioplankton. Arch. Hydrobiol. Spec. Issues Advanc. Limnol., 48: 31-38.
Reche, I., P. Carrillo \& L. Cruz-Pizarro. 1997. Influence of metazooplankton on interactions of bacteria and phytoplankton in an oligotrophic lake. J. Plankton Res., 19: 631-646.

Riccardi, N. 2002. In situ measurement of Daphnia longispina grazing on algae and bacteria in a high mountain lake (Lake Paione Superiore, Northern Italy) using fluorescently labelled cells. Water, air and soil pollution: (in press).

Roberts, E.C. \& J. Laybourn-Parry. 1999. Mixotrophic cryptophytes and their predators in the Dry Valley lakes of Antarctica. Freshwat. Biol., 41: 737-746.

Rothhaupt, K.O. 1996. Utilization of substitutable carbon and phosphorus sources by mixotrophic chrysophyte Ochromonas sp.. Ecology, 77: 706-715.

Rothhaupt, K.O. 1997. Nutrient turnover by freshwater bacterivorous flagellates: differences between a heterotrophic and a mixotrophic chrysophyte. Aquat. Microb. Ecol., 12: 65-70.

Salonen, K. \& S. Jokinen. 1988. Flagellate grazing on bacteria in a small dystrophic lake. Hydrobiologia, 161: 203-209.

Sherr, E.B. \& B.F. Sherr. 1993. Protistan grazing rates via uptake of fluorescently labeled prey. In: Kemp P., B. Sherr, E. Sherr \& J. Cole (Eds), Handbook of methods in aquatic microbial ecology. Lewis Publ., Boca Raton, FL: 695-701.

Simona, M., A. Barbieri, M. Veronesi, S. Malusardi \& V. Straškrabová. 1999. Seasonal dynamics of plankton in a mountain lake in the southern Alps (Laghetto Inferiore, Switzerland). J. Limnol., 58(2): 169-178.

Steeman Nielsen, E. 1951. Measurement of the production of organic matter in the sea by means of carbon-14. Nature, 167: 684-685.

Sterner, R.W., T.H. Chrzanowski, J.J. Elser \& N.B. George. 1995. Sources of nitrogen and phosphorus supporting the growth of bacterioplankton and phytoplankton in an oligotrophic Canadian Shield Lake. Limnol. Oceanogr., 40: 242-249.

Straškrabová, V., C. Callieri, P. Carrillo, L. Cruz-Pizarro, J. Fott, P. Hartman, M. Macek, J.M. Medina-Sánchez, J. Nedoma \& K. Šimek. 1999. Investigations on pelagic food webs in mountain lakes - aims and methods. J. Limnol., 58(2): 77-87.

The MOLAR Water Chemistry Group. 1999. The MOLAR project: atmospheric deposition and lake water chemistry. J. Limnol., 58(2): 88-106.

Tranvik, L.J., K.G. Porter \& J.McN. Sieburth. 1989. Occurrence of bacterivory in Cryptomonas, a common freshwater phytoplankter. Oecologia, 78: 473-476.

Urabe, J., T.B. Gurung, T. Yoshida, T. Sekino, M. Nakanishi, M. Maruo \& E. Nakayama. 2000. Diel changes in phagotrophy by Cryptomonas in Lake Biwa. Limnol. Oceanogr., 45: $1558-1563$.

Vaqué, D. \& L.M. Pace. 1992. Grazing on bacteria by flagellates and cladocerans in lakes of contrasting food-web structure. J. Plankton Res., 14: 307-321. 